\title{
Participation of $\mathrm{GA}_{3}$, ethylene, $\mathrm{NO}$ and $\mathrm{HCN}$ in germination of Amaranthus retroflexus $L$. seeds with various dormancy levels
}

\author{
Jan Kępczyński • Paweł Sznigir
}

Received: 23 September 2013/Revised: 16 January 2014/ Accepted: 19 March 2014/Published online: 13 April 2014

(C) The Author(s) 2014. This article is published with open access at Springerlink.com

\begin{abstract}
Amaranthus retroflexus seeds were dormant at $25^{\circ} \mathrm{C}$ in the darkness and in the light, and also at $35^{\circ} \mathrm{C}$ in the darkness. $\mathrm{GA}_{3}$ and ethylene partially removed dormancy at $35^{\circ} \mathrm{C}$ in the darkness and at $25^{\circ} \mathrm{C}$ in the light. Dormancy was removed by $1-5$ days of treatment with nitric oxide or cyanide. The effect of $\mathrm{NO}$ and $\mathrm{HCN}$ was inhibited by cPTIO, thus the effect of $\mathrm{HCN}$ was NO dependent. Dry storage for 16 weeks could partially release dormancy only at $35^{\circ} \mathrm{C}$, but not at $25^{\circ} \mathrm{C}$. Dry storage increased the response to light, $\mathrm{GA}_{3}$ and ethylene. The response to $\mathrm{GA}_{3}$ and ethylene at $25{ }^{\circ} \mathrm{C}$ was enhanced with increasing storage temperature. $\mathrm{GA}_{3}$, ethylene and nitric oxide could substitute dry storage and stratification in partially dormant seeds.
\end{abstract}

Keywords Amaranthus retroflexus - Plant hormones . Primary dormancy $\cdot$ Stratification $\cdot$ Dry storage $\cdot \mathrm{NO} \cdot \mathrm{HCN}$

\section{Introduction}

Seeds of Amaranthus retroflexus, a common important annual weed widely occurring in agricultural fields, are primarily physiologically dormant after the harvest (Baskin and Baskin 2001). Dormancy of these seeds can be removed by means of burial in late autumn and winter

Communicated by J. V. Staden.

J. Kępczyński $(\bowtie) \cdot$ P. Sznigir

Chair of Plant Physiology and Genetic Engineering, Faculty of Biology, University of Szczecin, Wąska 13, 71-415 Szczecin, Poland

e-mail: jankepcz@wp.pl
(Egley 1989; Kępczyński and Sznigir 2013). Likewise, cold stratification may release dormancy in these seeds, however, less effectively than burial (Kępczyński and Sznigir 2013). A. retroflexus seed dormancy is controlled hormonally. $\mathrm{GA}_{3}$ can remove dormancy of the above seeds (Kępczyński et al. 1996). Likewise, ethephon, ethylene and the precursor of ethylene biosynthesis ACC, stimulate germination of these dormant seeds (Kępczyński et al. 1996, 2003b). Ethylene biosynthesis and action are involved in releasing dormancy of A. retroflexus seeds by $\mathrm{GA}_{3}$ (Kępczyński et al. 2003b). Recently, it has been reported that both $\mathrm{GA}_{3}$ and ethylene can partially substitute the requirement for autumn-winter burial or cold stratification (Kępczyński and Sznigir 2013).

Instead of burial, stratification and hormones also dry storage (after-ripening) of seeds can release dormancy in several plant species e.g., Amaranthus retroflexus (Schönbeck and Egley 1980), Arabidopsis thaliana (Cadman et al. 2006), Hordeum vulgare (Gubler et al. 2008), Sisymbrium officinale (Iglesias-Fernandez and Matilla 2009) and Avena fatua (Kępczyński et al. 2013). Moreover, nitrogen-containing compounds such as nitrate, nitrite, hydroxylamine and azide have been known to break dormancy of seeds (Hendricks and Taylorson 1974). Hendricks and Taylorson suggested that NO was a product of the azide, hydroxylamine and nitrite applied to seeds. Later, many papers considering the effect of NO, by using its different donors, on the germination of dormant and non-dormant seeds were published (Bethke et al. 2007). Sodium nitroprusside (SNP), producing both $\mathrm{NO}$ and $\mathrm{HCN}$ in the light (Feelisch 1998), releases dormancy of lettuce (Beligni and Lamattina 2000), barley (Bethke et al. 2004), Arabidopsis (Bethke et al. 2004, 2006a), A. retroflexus seeds (Liu et al. 2011) and Malus domestica embryos (Gniazdowska et al. 2007, 2010). Likewise, $\mathrm{HCN}$ released from $\mathrm{Fe}(\mathrm{II}) \mathrm{CN}$ or 
$\mathrm{Fe}(\mathrm{III}) \mathrm{CN}$ can reduce dormancy in Arabidopsis (Bethke et al. 2006b), A. retroflexus seeds (Liu et al. 2011) and Malus domestica embryos (Gniazdowska et al. 2010). There are no data on the effect of gibberellins, ethylene, $\mathrm{NO}$ and $\mathrm{HCN}$ on germination of dry stored or stratified A. retroflexus seeds.

The aim of the present study was to determine the importance of $\mathrm{GA}_{3}$, ethylene, $\mathrm{NO}$ and $\mathrm{HCN}$ in germination of seeds that were dormant and partially dormant due to dry storage (after-ripening) or stratification.

\section{Materials and methods}

Plant material

Amaranthus retroflexus seeds were collected from wild populations in September 2006 near Lubniewice in Poland. The inflorescences were stored in open air for 3 weeks and then shaken gently to remove seeds. After drying for 10 days, they were stored at $-20{ }^{\circ} \mathrm{C}$ until they were needed.

\section{Dry storage and stratification}

In order to release dormancy resulting from dry storage, seeds $(15 \mathrm{~g})$ were placed in open 0.51 jars and stored in darkness at $5 \pm 2,15 \pm 0.5,20 \pm 0.5,25 \pm 0.5$ and $35 \pm 0.5^{\circ} \mathrm{C}$. For stratification, seeds $(0.9 \mathrm{~g})$ were placed in 12-cm diameter Petri dishes lined with three layers of filter paper moistened with 12-ml distilled water. Petri dishes were sealed with parafilm to maintain humidity, and were kept in darkness at $4{ }^{\circ} \mathrm{C}$.

Treatment with gibberellin $\mathrm{A}_{3}\left(\mathrm{GA}_{3}\right)$ or 2-chloroethylphosphonic acid (ethephon)

After $0,8,12$ and 16 weeks of dry storage, seeds were incubated in 6-cm Petri dishes on filter paper moistened with $1.5-\mathrm{ml}$ water or solutions of $\mathrm{GA}_{3}\left(10^{-3} \mathrm{M}\right)$ and ethephon $\left(10^{-4} \mathrm{M}\right)$ in darkness at 25 and $35^{\circ} \mathrm{C}$, for 7 days. After 8 weeks of stratification, seeds were incubated in 6-cm Petri dishes with filter paper moistened with $1.5-\mathrm{ml}$ water or solutions of $\mathrm{GA}_{3}\left(10^{-4}, 10^{-3} \mathrm{M}\right)$ or ethephon $\left(10^{-5}, 10^{-4} \mathrm{M}\right)$ in the light $\left(120 \mu \mathrm{Em}^{-2} \mathrm{~s}^{-1}, 16 / 8 \mathrm{~h}\right)$ at $25^{\circ} \mathrm{C}$ for 7 days.

Treatment with gases released from sodium nitroprusside (SNP) or potassium ferrocyanide ( $\mathrm{Fe}(\mathrm{II}) \mathrm{CN})$

Seeds (50) were placed in 3-cm Petri dishes on filter paper moistened with $0.8-\mathrm{ml}$ water. Three open Petri dishes with seeds and one open 5-cm Petri donor dish containing $3.6 \mathrm{ml}\left(10^{-5}, 3 \times 10^{-5}, 10^{-4}, 3 \times 10^{-4} \mathrm{M}\right)$ of SNP or $\mathrm{Fe}(\mathrm{II}) \mathrm{CN}$ solutions were enclosed in a $12-\mathrm{cm}$ Petri dish and sealed with Parafilm. Petri dishes were kept in the light $\left(120 \mu \mathrm{Em}^{-2} \mathrm{~s}^{-1}, 16 / 8 \mathrm{~h}\right)$ at $25{ }^{\circ} \mathrm{C}$ for 1,3 or 5 days. After 1 and 3 days, Petri dishes with donor solutions were replaced with Petri dishes containing water. In the experiment with cPTIO, three Petri dishes with seeds on filter paper moistened with 2-(4-carboxyphenyl)-4,4,5,5-tetramethylimidazoline-1-oxyl-3-oxide (cPTIO) solutions $\left(5 \times 10^{-5}, 10^{-4} \mathrm{M}\right)$ were kept for 1 day in a $12-\mathrm{cm}$ Petri dish containing $3.6 \mathrm{ml}$ SNP $\left(10^{-4} \mathrm{M}\right)$ or $\mathrm{Fe}(\mathrm{II}) \mathrm{CN}$ $\left(10^{-4} \mathrm{M}\right)$.

Seeds after-ripened for 8 or 16 weeks were incubated for 1 day in the presence of the Petri dish with SNP $\left(3 \times 10^{-5}, 10^{-4}, 3 \times 10^{-4} \mathrm{M}\right)$ or $\mathrm{Fe}(\mathrm{II}) \mathrm{CN}\left(3 \times 10^{-5}\right.$, $\left.10^{-4}, 3 \times 10^{-4} \mathrm{M}\right)$, in the light, at $25^{\circ} \mathrm{C}$. Seeds stratified for 8 weeks were incubated for 1 day in the presence of SNP $\left(10^{-5}, 10^{-4} \mathrm{M}\right)$, also in the light, at $25^{\circ} \mathrm{C}$.

In all experiments, germination was determined during 5 or 7 days of incubation under appropriate conditions (25 and $35{ }^{\circ} \mathrm{C}$ in the darkness or $25^{\circ} \mathrm{C}$ in the light). Seeds were regarded as germinated when the radicle protruded through the seed coat and was longer than $2 \mathrm{~mm}$. All manipulations were performed under green light.

Results were presented as a final percentage of seed germination. Furthermore, the rate of germination was presented according to Timson (1965) by calculating the value of $\sum_{7}\left(\sum_{7}=700\right.$ means that $100 \%$ of seeds germinated on the first day).

\section{Statistical analysis}

The average \pm standard deviation (SD) of three independent determinations from 50 seeds each is presented. Data have been analyzed for significance using one-way or twoway ANOVA (Statistica for Windows ver. 9.0, StatSoft Inc. Tulsa, Oklahoma, USA). Duncan's multiple range test has been used for the determination of significant differences between germination values $(P<0.05)$.

\section{Results}

The effect of $\mathrm{GA}_{3}$ and ethephon on seed germination at 25 and $35{ }^{\circ} \mathrm{C}$ after dry storage at $5,15,25$ and $35^{\circ} \mathrm{C}$ in the darkness.

Germination at $25{ }^{\circ} \mathrm{C}$

Non-after-ripened (dormant) and dry-stored (after-ripened) seeds at the temperatures from 5 to $35^{\circ} \mathrm{C}$ for up to 16 weeks germinated very poorly at $25{ }^{\circ} \mathrm{C}$; between 3 and $10 \%$ of 
Fig. 1 Effect of $\mathrm{GA}_{3}$ and ethephon on final percentage (a) and rate (b) germination of A. retroflexus seeds in darkness at $25{ }^{\circ} \mathrm{C}$ after dry storage for 8 , 12 and 16 weeks at $5,15,25$ and $35{ }^{\circ} \mathrm{C}$. Germination was determined during 7 days of incubation. The vertical bars indicate $\pm \mathrm{SD}$. Two-way ANOVA with the Duncan post hoc test was used to determine significant differences. Mean values with different letters are significantly different $(P<0.05)$
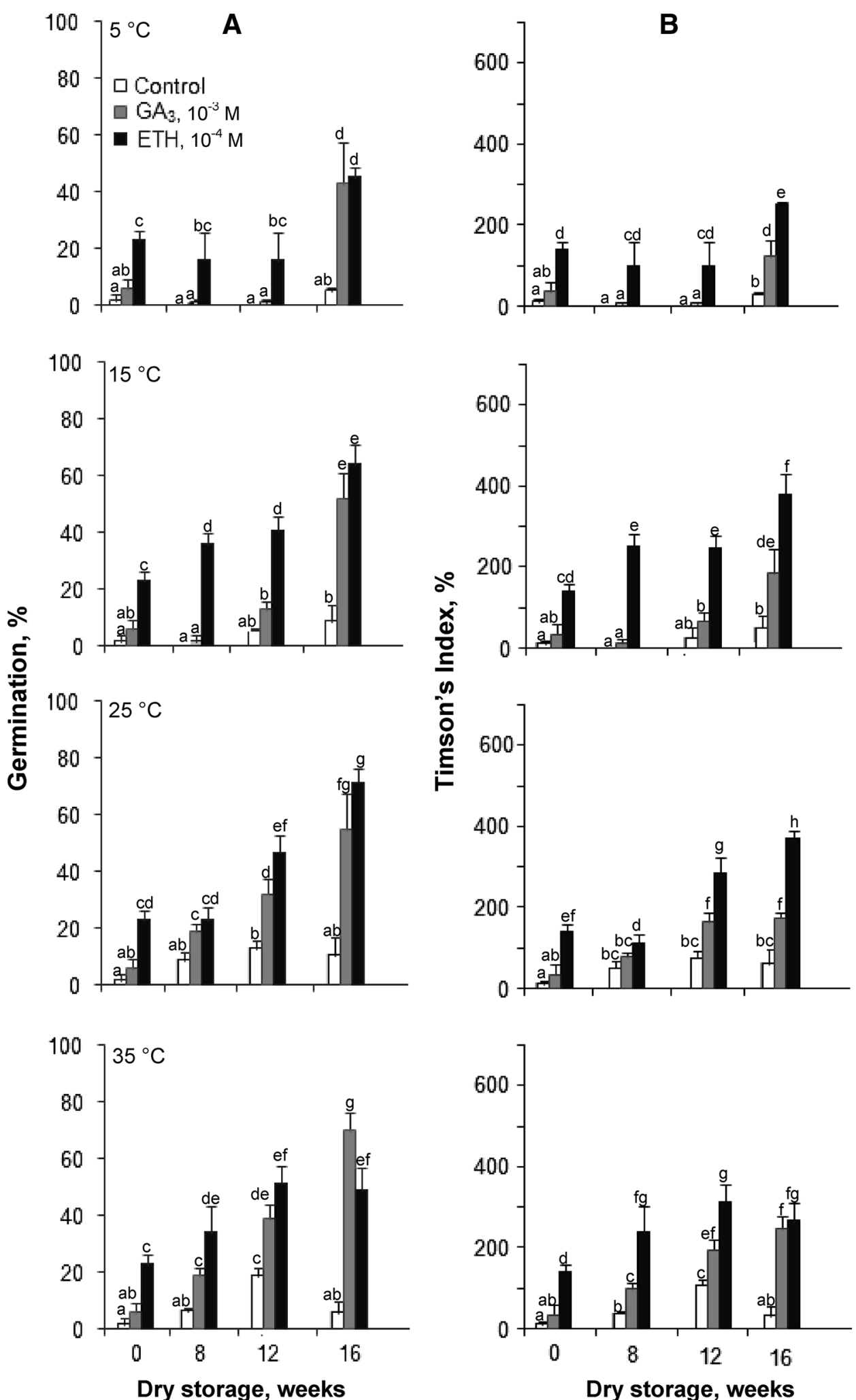

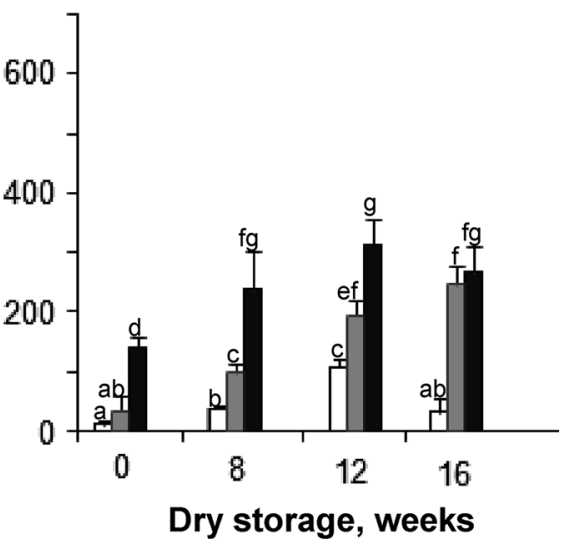

seeds germinated (Fig. 1). GA 3 did not affect the germination of unstored seeds and seeds stored at 5 and $15{ }^{\circ} \mathrm{C}$ up to 12 weeks. This hormone increased the germination of seeds stored for 16 weeks at 5 and $15{ }^{\circ} \mathrm{C} ; 40-50 \%$ of seeds germinated. In the case of seeds dry stored at 25 and $35^{\circ} \mathrm{C}$, the stimulatory effect of $\mathrm{GA}_{3}$ became apparent just after 8 weeks of storage. The effect of $\mathrm{GA}_{3}$ increased with the passage of storage time at these temperatures. Maximal 
effect of this hormone was noted when seeds were stored for 16 weeks at $35{ }^{\circ} \mathrm{C}$ : germination reached $70 \%$. Ethephon enhanced the germination of unstored seeds and seeds stored for 16 weeks at $5{ }^{\circ} \mathrm{C}$ for up to ca. 20 and $40 \%$, respectively. This compound also increased the germination of seeds stored at $15-35^{\circ} \mathrm{C}$ for the period of 8 to 16 weeks. The stimulatory effect of this regulator was also enhanced with the length of dry storage; the seeds reached ca. 50-70\% germination when stored for 16 weeks. Both compounds increased markedly the rate of seed germination after various periods of dry storage (Fig. 1b).

Germination at $35^{\circ} \mathrm{C}$

At $35^{\circ} \mathrm{C}$, similarly as at $25^{\circ} \mathrm{C}$, non-after-ripened seeds germinated very poorly: only $5 \%$ germinated (Fig. 2). Dry storage at 5 and $15{ }^{\circ} \mathrm{C}$ for up to 12 weeks did not affect seed germination. 16 weeks at these temperatures resulted in 10-30\% germination. Dry storage at 25 and $35^{\circ} \mathrm{C}$ for up to 12 weeks slightly increased germination. After 16 weeks of dry storage at 25 and $35^{\circ} \mathrm{C}$, seed germination reached 40 and $70 \%$, respectively. $\mathrm{GA}_{3}$ increased germination of unstored seeds. Percentage germination in the presence of $\mathrm{GA}_{3}$ increased with the prolongation of dry storage periods. For all storage temperatures, the highest level of germination in the presence of $\mathrm{GA}_{3}$ was observed after 16 weeks. Almost all seeds stored for 16 weeks at all temperatures were able to germinate in the presence of $\mathrm{GA}_{3}$. Ethephon enhanced the germination of unstored and stored seeds for various periods at all temperatures, also progressively with storage time. The percentage germination after 16 weeks of storage at $5-35^{\circ} \mathrm{C}$ reached 75-85\%. Both $\mathrm{GA}_{3}$ and ethephon increased the rate of seed germination in a similar fashion (Fig. 2b).

\section{The effect of gases released from SNP and $\mathrm{Fe}(\mathrm{II}) \mathrm{CN}$ applied in the absence or presence of $\mathrm{CPTIO}$ on germination of dormant seeds at $25^{\circ} \mathrm{C}$ in the light}

Gases $(\mathrm{NO}+\mathrm{HCN})$ released from SNP donor, applied at all concentrations for 1-5 days enhanced the percentage of seed germination (Fig. 3a). The highest percentage of germination was observed when the donor was used at the highest concentration, i.e., $3 \times 10^{-4} \mathrm{M}$, for 1 day; ca. $60 \%$ seeds germinated in comparison to $5 \%$ in the control group. SNP application at $10^{-4}$ and $3 \times 10^{-4} \mathrm{M}$ for 3 days resulted in a similar level of germination as was observed after using $3 \times 10^{-4} \mathrm{M}$ for 1 day. After 5 days of the treatment, the effects of $10^{-4}$ and $3 \times 10^{-4} \mathrm{M}$ SNP gases were similar. However, the effect of $3 \times 10^{-4} \mathrm{M}$ SNP applied for 5 days was lower than after 1 or 3 days. The stimulatory effect of SNP was also evident when the rate of germination was considered (Fig. 3b). The highest rate increase was found when SNP was used at $3 \times 10^{-4}$ or 3 $\times 10^{-5} \mathrm{M}$ for 1 day or 5 days, respectively. Likewise, the gas $(\mathrm{HCN})$ released from $\mathrm{Fe}(\mathrm{II}) \mathrm{CN}$ increased the percentage of germination, the effect being dependent on its concentration (Fig. 3c). The strongest effect was observed after the application of $\mathrm{Fe}(\mathrm{II}) \mathrm{CN}$ at two highest concentrations $10^{-4}$ and $3 \times 10^{-4} \mathrm{M}$ for 1 day or $3 \times 10^{-5}$ $3 \times 10^{-4} \mathrm{M}$ for 3 and for 5 days; ca. $40 \%$ of germination. The stimulatory effect of $\mathrm{HCN}$, as in the case of $\mathrm{NO}+\mathrm{HCN}$, was also evident when the rate of germination was analyzed (Fig. 3d). The highest rate was found when $\mathrm{Fe}(\mathrm{II}) \mathrm{CN}$ at $10^{-4}$ and $3 \times 10^{-4}$ or $3 \times 10^{-5} \mathrm{M}$ was used for 1 day or 5 days, respectively.

In the following experiment, seeds were incubated for 5 days in the presence of gases released from SNP or $\mathrm{Fe}(\mathrm{II}) \mathrm{CN}$ and water or the solution of cPTIO (Table 1). The percentage of untreated seeds reached only $7 \%$ after 5 days of incubation. $\mathrm{NO}+\mathrm{HCN}$ released from $\mathrm{SNP}$ or $\mathrm{HCN}$ from $\mathrm{Fe}(\mathrm{II}) \mathrm{CN}$ caused ca. $40 \%$ of seeds to germinate. The cPTIO, depending on concentration, decreased or completely inhibited the germination of dormant seeds. Simultaneous incubation in the presence of $\mathrm{CPTIO}$ and $\mathrm{NO}+\mathrm{HCN}$ or $\mathrm{NO}$ caused seed germination at similar level as in the case of untreated seeds. Thus, stimulatory effect of gases released from SNP or HCN did not occur because of cPTIO.

The effect of gases released from SNP or Fe(II)CN on the germination at $25{ }^{\circ} \mathrm{C}$ of dry-stored seeds at 5, 25 and $35^{\circ} \mathrm{C}$ for 8 and 16 weeks

The percentage of seeds that were dry stored for 8 and 16 weeks at 5,25 or $35^{\circ} \mathrm{C}$ and germinated in the light was ca. 50-60 \% and 65-80\%, respectively (Fig. 4). Seed incubation for 1 day in the presence of $\mathrm{NO}+\mathrm{HCN}$ gases from SNP increased the germination of seeds stored for 8 and 16 weeks. $\mathrm{SNP}$ at $3 \times 10^{-5} \mathrm{M}$ caused $65-80 \%$ the germination of seeds stored at $5-35^{\circ} \mathrm{C}$ for 8 weeks. The application of SNP at $10^{-4} \mathrm{M}$ to seeds stored for 8 weeks at 5,25 and $35^{\circ} \mathrm{C}$ allowed 80-90\% of seeds to germinate. After 16 weeks of storage at 5 and $25^{\circ} \mathrm{C}$, the SNP from $3 \times 10^{-5} \mathrm{M}$ allowed for $80-90 \%$ germination. $\mathrm{Fe}(\mathrm{II}) \mathrm{CN}$ at $3 \times 10^{-5} \mathrm{M}$ slightly increased the germination percentage of seeds dry stored for 8 weeks at $5{ }^{\circ} \mathrm{C}$ and markedly of those dry stored for 16 weeks only at 5 and $25^{\circ} \mathrm{C}$. At a higher concentration of this compound, almost total germination was noted when seeds were stored for 8 or 16 weeks at 5,25 or $35^{\circ} \mathrm{C}$.

The effect of stratification, $\mathrm{GA}_{3}$, ethephon and gases released from SNP on seed germination at $25^{\circ} \mathrm{C}$ in the light

Very few non-stratified seeds germinated at $25{ }^{\circ} \mathrm{C}$ in the light (Table 2). $\mathrm{GA}_{3}$ at $10^{-4} \mathrm{M}$ did not affect the germination, but 
Fig. 2 Effect of $\mathrm{GA}_{3}$ and ethephon on final percentage (a) and rate (b) germination of A. retroflexus seeds in darkness at $35{ }^{\circ} \mathrm{C}$ after dry storage for 8 , 12 and 16 weeks at $5,15,25$ and $35^{\circ} \mathrm{C}$. Germination was determined during 7 days of incubation. The vertical bars indicate \pm SD. Two-way ANOVA with the Duncan post hoc test was used to determine significant differences. Mean values with different letters are significantly different $(P<0.05)$
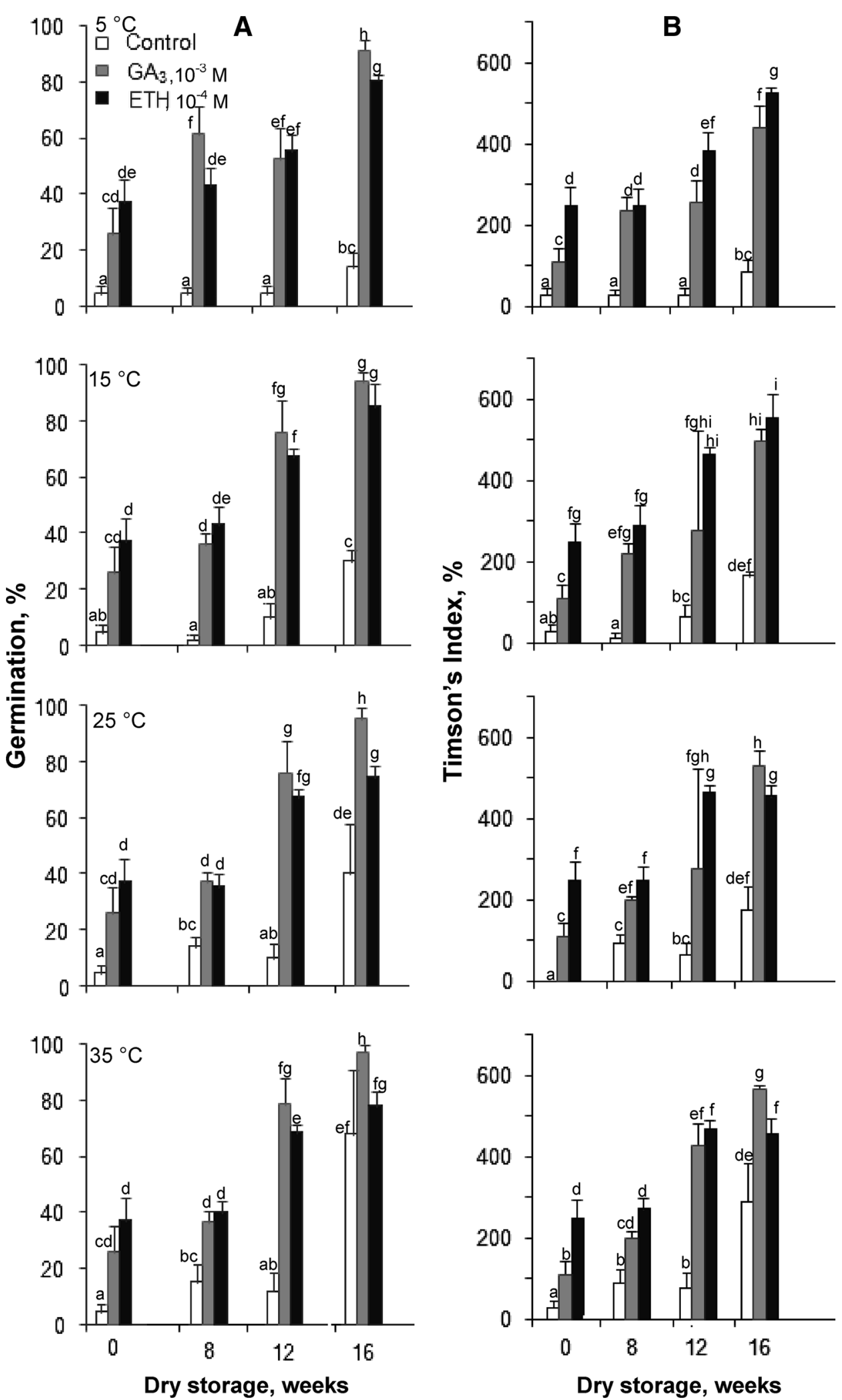

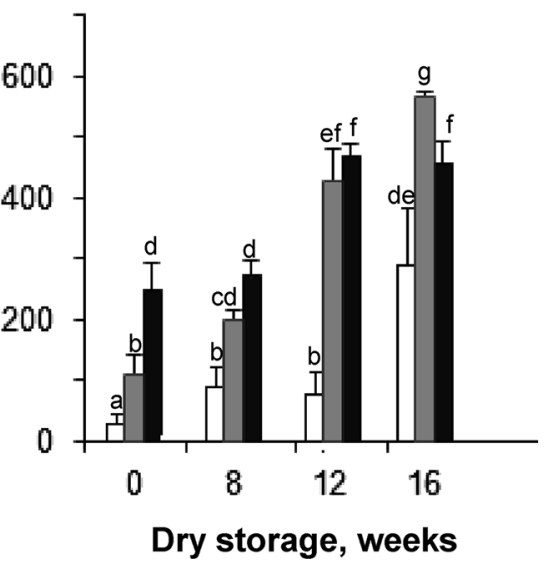

at $10^{-3}$ half of the seeds were able to germinate. Ethephon at $10^{-5}$ and $10^{-4} \mathrm{M}$ markedly increased germination; it reached ca. 40-70\%. Stratification for 8 weeks increased seed germination percentage and half of the seeds were able to germinate. Regardless of its concentration, $\mathrm{GA}_{3}$ allowed for $60-80 \%$ seed germination after 8 weeks of stratification. The application of ethephon at all concentrations resulted in ca. $90 \%$ germination. SNP at $10^{-5}$ and $10^{-4} \mathrm{M}$ increased 


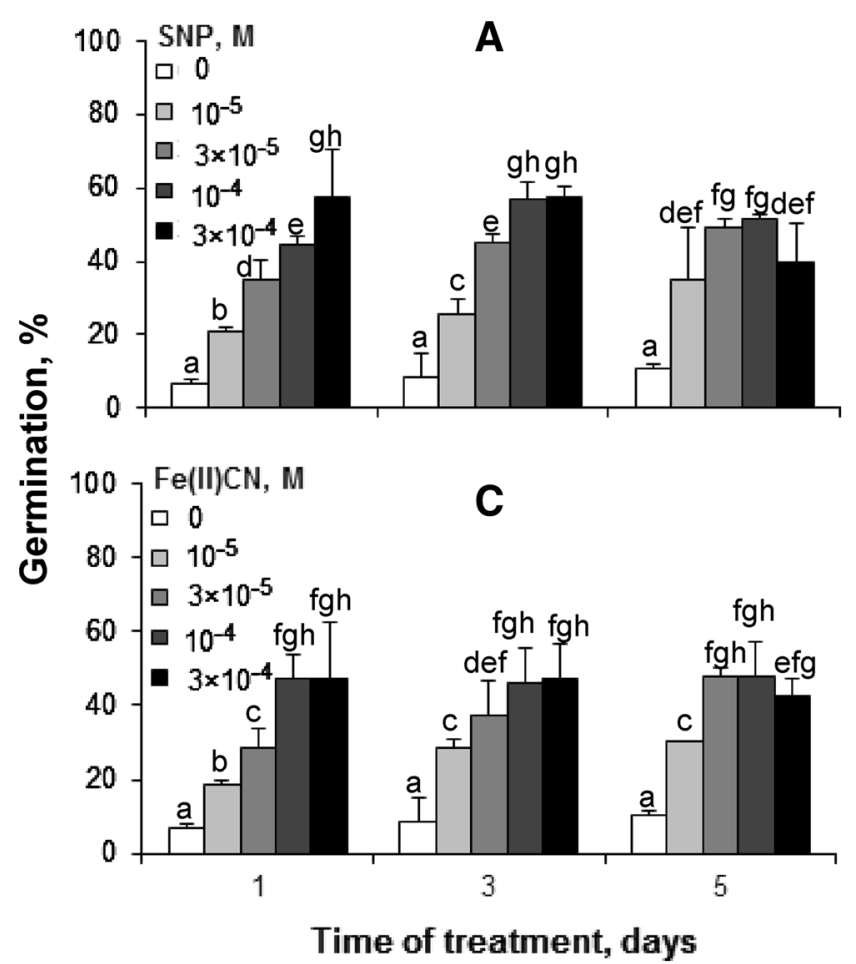

Fig. 3 Effect of gases released from SNP or Fe(II)CN donor applied during 1, 3 and 5 days of incubation in the light $\left(120 \mu \mathrm{mol} \mathrm{m}^{-2} \mathrm{~s}^{-1}\right)$ on final percentage $(\mathbf{a}, \mathbf{c})$ and rate $(\mathbf{b}, \mathbf{d})$ of germination of $A$. retroflexus seeds at $25^{\circ} \mathrm{C}$. After treatment with gases for 1 or 3 days seeds were further incubated up to 5 days in air. Germination was

Table 1 Effect of cPTIO in the absence and presence of gases released from $\mathrm{SNP}$ or $\mathrm{Fe}(\mathrm{II}) \mathrm{CN}$ on $A$. retroflexus seed germination at $25{ }^{\circ} \mathrm{C}$ in the light

\begin{tabular}{llc}
\hline Treatment & \multicolumn{2}{l}{ Germination (\%) } \\
\cline { 2 - 3 } & \multicolumn{2}{l}{ Days } \\
\cline { 2 - 3 } & 2 & 5 \\
\hline Control & $2 \pm 3.5 \mathrm{a}$ & $7.3 \pm 4.2 \mathrm{ab}$ \\
cPTIO, $5 \times 10^{-5} \mathrm{M}$ & $0 \pm 0 \mathrm{a}$ & $0.7 \pm 1.2 \mathrm{a}$ \\
cPTIO, $10^{-4} \mathrm{M}$ & $0 \pm 0 \mathrm{a}$ & $0 \pm 0 \mathrm{a}$ \\
SNP, $10^{-4} \mathrm{M}$ & $8 \pm 5.3 \mathrm{ab}$ & $42 \pm 8.7 \mathrm{c}$ \\
cPTIO, $5 \times 10^{-5} \mathrm{M}+\mathrm{SNP}$ & $0 \pm 0 \mathrm{a}$ & $8.7 \pm 2.3 \mathrm{ab}$ \\
cPTIO, $10^{-4} \mathrm{M}+\mathrm{SNP}$ & $0 \pm 0 \mathrm{a}$ & $7.3 \pm 4.2 \mathrm{ab}$ \\
Fe(II)CN, $10^{-4} \mathrm{M}$ & $0 \pm 0 \mathrm{a}$ & $38 \pm 6.9 \mathrm{c}$ \\
cPTIO, $5 \times 10^{-5} \mathrm{M}+\mathrm{Fe}(\mathrm{II}) \mathrm{CN}$ & $0 \pm 0 \mathrm{a}$ & $5.3 \pm 3.1 \mathrm{a}$ \\
cPTIO, $10^{-4} \mathrm{M}+\mathrm{Fe}(\mathrm{II}) \mathrm{CN}$ & $0 \pm 0 \mathrm{a}$ & $6.0 \pm 5.3 \mathrm{a}$ \\
\hline
\end{tabular}

cPTIO and SNP or Fe(II)CN were present during whole period of incubation. Two-way ANOVA with the Duncan post hoc test was used to determine significant differences

Mean values with different letters are significantly different $(P<0.05)$

the germination of unstratified seeds. Almost all partly stratified seeds could germinate when SNP at $10^{-4} \mathrm{M}$ was used.

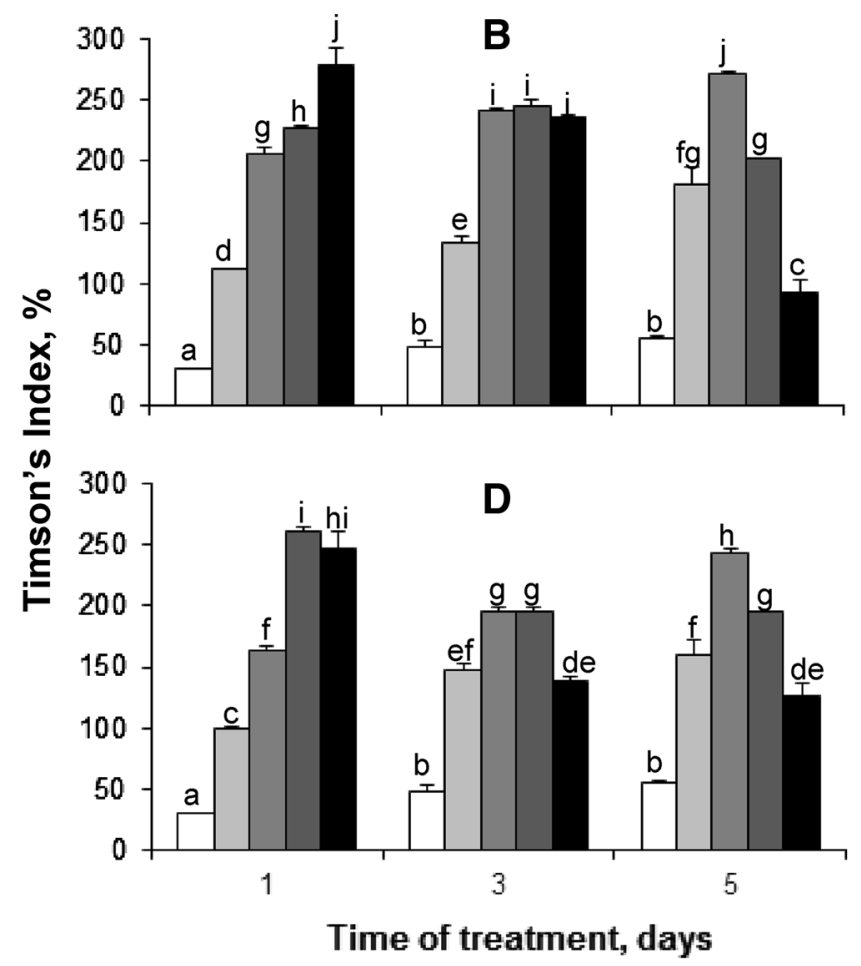

determined every day. The vertical bars indicate \pm SD. Two-way ANOVA with the Duncan post hoc test was used to determine significant differences. Mean values with different letters are significantly different $(P<0.05)$

\section{Discussion}

Control germination of dormant seeds in the darkness

Seeds of the common weed A. retroflexus could not germinate in the darkness at 25 and $35^{\circ} \mathrm{C}$ (Kępczyński and Sznigir 2013, figs. 1, 2) because they were primarily dormant. Dormancy in seeds of many wild and cultivated plant species can be effectively removed by dry storage (after-ripening). Seeds of Arabidopsis Cvi required 20 weeks at $21 / 24{ }^{\circ} \mathrm{C}$ (Ali-Rachedi et al. 2004), S. officinale required 24 weeks at $21{ }^{\circ} \mathrm{C}$ (Iglesias-Fernandez and Matilla 2009) and A. fatua required 12 weeks at $25^{\circ} \mathrm{C}$ (Kępczyński and Van Staden 2012) for releasing dormancy. Dry storage of dormant $A$. retroflexus seeds for up to 16 weeks did not affect germination at $25{ }^{\circ} \mathrm{C}$ (Fig. 1), thus it was insufficient to release dormancy at this temperature. However, at a higher temperature, i.e., at $35{ }^{\circ} \mathrm{C}$, seed dormancy was released as a result of dry storage at $25-35{ }^{\circ} \mathrm{C}$ for 16 weeks since it allowed for $40-70 \%$ germination (Fig. 2). In an earlier study, it had been shown that dry storage at varying temperatures, i.e., 24-28 ${ }^{\circ} \mathrm{C}$, for 5 months increased the germination of $A$. retroflexus seeds at $35{ }^{\circ} \mathrm{C}$ from 11 up to $70 \%$ (Schönbeck 
$5^{\circ} \mathrm{C}$

$25^{\circ} \mathrm{C}$

$35^{\circ} \mathrm{C}$
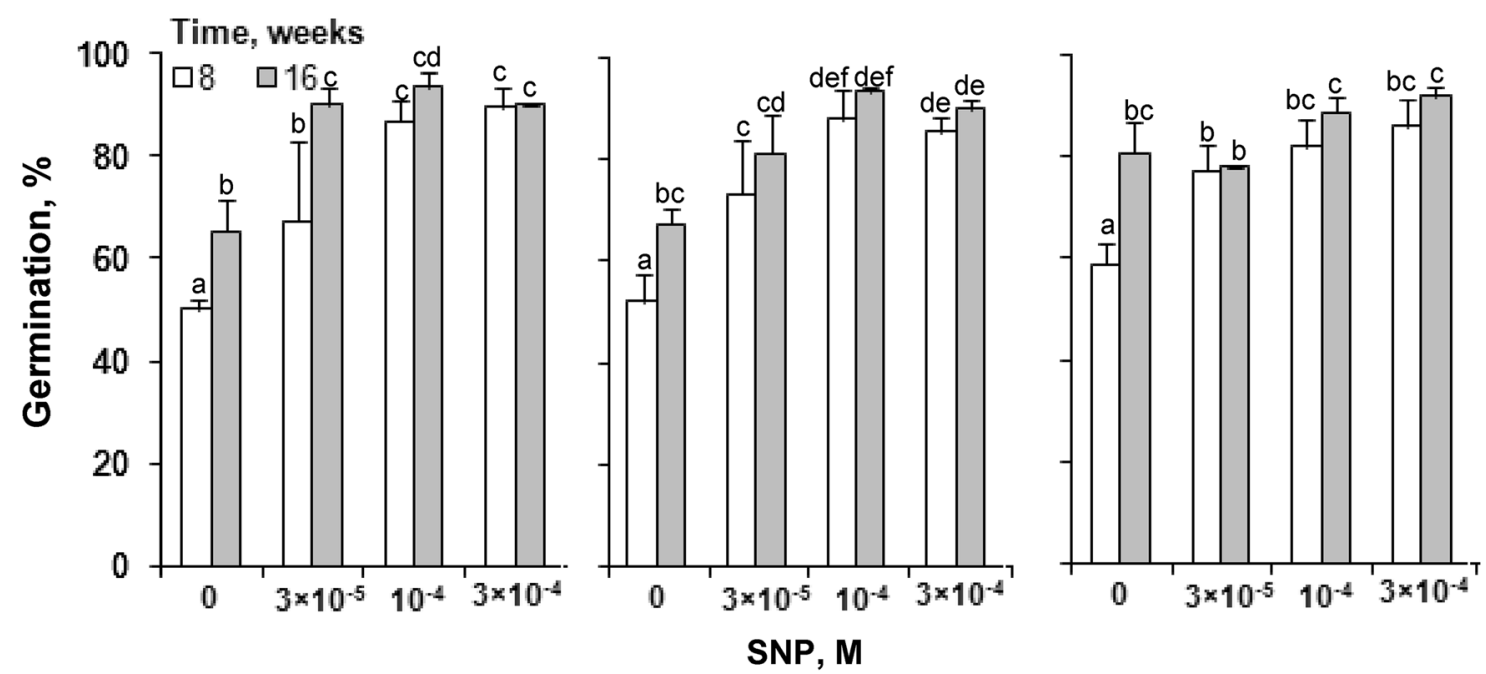

$5^{\circ} \mathrm{C}$

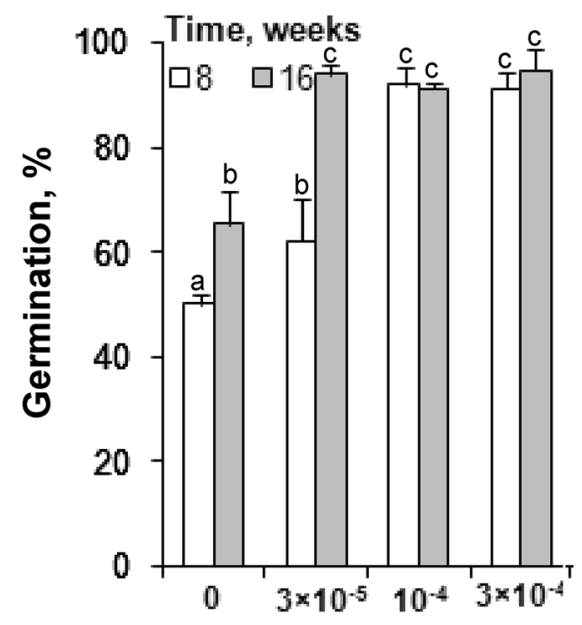

$25^{\circ} \mathrm{C}$

$35^{\circ} \mathrm{C}$
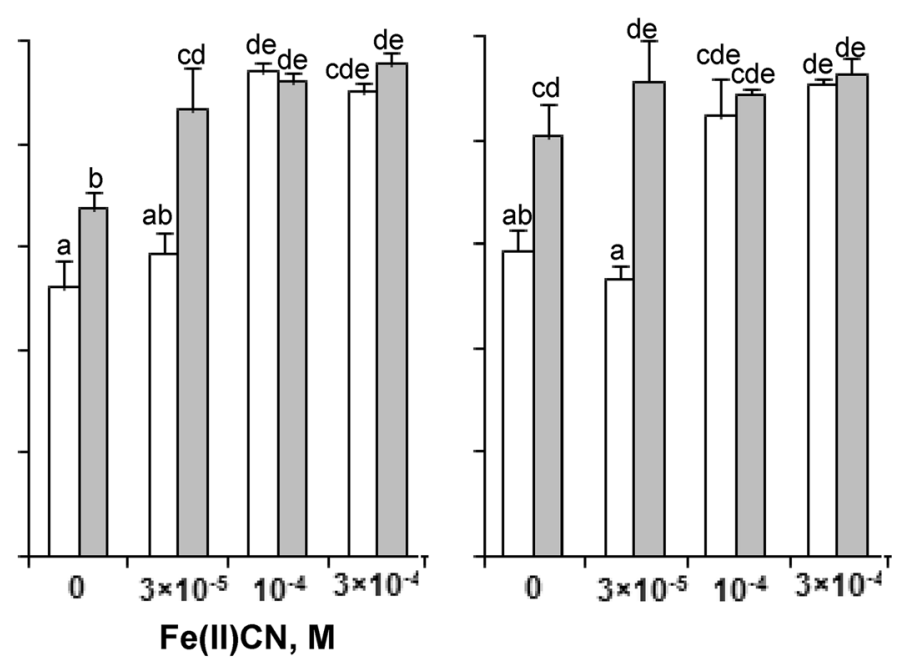

Fig. 4 Effect of gases released from SNP or Fe(II)CN on percentage germination of A. retroflexus seeds at $25{ }^{\circ} \mathrm{C}$ after dry storage for 8 and 16 weeks at 5,25 and $35^{\circ} \mathrm{C}$. SNP was applied in the light for 1 day. Germination was determined after 7 days of incubation. The vertical

bars indicate \pm SD. Two-way ANOVA with the Duncan post hoc test was used to determine significant differences. Mean values with different letters are significantly different $(P<0.05)$

and Egley 1980). Thus, dry storage, similarly as in other seeds with physiological dormancy can remove dormancy in A. retroflexus seeds. The presented data also proved that the rate of dormancy releasing in A. retroflexus seeds, as in the case of many other seeds (Baskin and Baskin 1976) increased together with an increasing storage temperature; about five times more seeds germinated when stored for 16 weeks at $35{ }^{\circ} \mathrm{C}$ than at $5{ }^{\circ} \mathrm{C}$ (Fig. 2). The mechanism of releasing dormancy during after-ripening is not completely known. It has been considered that nonenzymatic reactions removing germination inhibitors, plant hormones, reactive oxygen species, membrane alterations, specific protein degradation and the expression of genes can be involved in releasing dormancy during dry storage (Hallet and Bewley 2002; Finch-Savage and LeubnerMetzger 2006; El-Maarouf-Bouteau and Bailly 2008; Hilhorst 2007). Dormant A. retroflexus seeds responded partially to $\mathrm{GA}_{3}$ at $35{ }^{\circ} \mathrm{C}$, but not at $25^{\circ} \mathrm{C}$, and to ethylene, liberated from ethephon, at both temperatures (Kępczyński and Sznigir 2013, figs. 1, 2). Although dry storage did not much affect the state of dormancy at $25{ }^{\circ} \mathrm{C}$, measured as visible germination at this temperature, however it increased the response of the seeds to $\mathrm{GA}_{3}$ and ethylene (Fig. 1). The seeds that were after-ripened at various temperatures were more responsive to $\mathrm{GA}_{3}$ and ethylene at 35 than at $25^{\circ} \mathrm{C}$. The releasing 
Table 2 Effect of $\mathrm{GA}_{3}$ and ethephon and gases released from SNP after 8 weeks of stratification at $4{ }^{\circ} \mathrm{C}$ on A. retroflexus seed germination at $25{ }^{\circ} \mathrm{C}$ in the light

\begin{tabular}{cll}
\hline Treatment & \multicolumn{2}{l}{ Germination (\%) } \\
\cline { 2 - 3 } & \multicolumn{2}{l}{ Stratification (weeks) } \\
\cline { 2 - 3 } & 0 & 8 \\
\hline Control & $8 \pm 3 \mathrm{ab}$ & $53 \pm 7 \mathrm{ef}$ \\
ETH (M) & $38 \pm 4 \mathrm{~d}$ & $90 \pm 2 \mathrm{ij}$ \\
$10^{-5}$ & $66 \pm 7 \mathrm{~g}$ & $89 \pm 5 \mathrm{hij}$ \\
$10^{-4}$ & $15 \pm 6 \mathrm{bc}$ & $57 \pm 4 \mathrm{fg}$ \\
$\mathrm{GA}_{3}(\mathrm{M})$ & $52 \pm 7 \mathrm{ef}$ & $81 \pm 5 \mathrm{hi}$ \\
$10^{-4}$ & & \\
$10^{-3}$ & $6.7 \pm 1.2 \mathrm{a}$ & $47 \pm 11 \mathrm{c}$ \\
$\mathrm{Control}$ & & $73 \pm 3.1 \mathrm{~d}$ \\
$\mathrm{SNP}(\mathrm{M})$ & $21 \pm 1.2 \mathrm{~b}$ & $87 \pm 9 \mathrm{e}$ \\
$10^{-5}$ & $45 \pm 2.3 \mathrm{c}$ & \\
$10^{-4}$ & & \\
\hline
\end{tabular}

Germination was determined after 7 days. Two-way ANOVA with the Duncan post hoc test was used to determine significant differences

Mean values with different letters are significantly different $(P<0.05)$

dormancy action of both hormones, applied at 25 or $35^{\circ} \mathrm{C}$, increased with the extension of storage time (Figs. 1, 2). Such results are in good agreement with data obtained on A. thaliana seeds (Karssen et al. 1989), S. officinale seeds (Iglesias-Fernandez and Matilla 2009) and A. fatua caryopses (Kępczyński et al. 2013) where afterripening increased the response to gibberellin and/or ethylene.

Control germination of dormant seeds in the light

A. retroflexus seeds, similarly as in the darkness, could not germinate in the light because of primary dormancy (Fig. 3). Stratification increased their sensitivity to light; ca. $15 \%$ seeds stratified for 8 weeks germinated in the darkness at $25{ }^{\circ} \mathrm{C}$ (Kępczyński and Sznigir 2013), however, more than half germinated in the light at the same temperature (Table 2). Dry storage also increased the sensitivity to light (Figs. 1, 4). Both $\mathrm{GA}_{3}$ and ethylene could partially remove dormancy and ethylene was found to be more effective than $\mathrm{GA}_{3}$ (Fig. 1; Table 2). A comparison of the effect of these hormones in the darkness and in the light indicated that the light increased the response to $\mathrm{GA}_{3}$ and ethylene (Fig. 1; Table 2). Stratification enhanced the response to $\mathrm{GA}_{3}$ and ethylene only in the darkness (Kępczyński and Sznigir 2013, Table 2).

Gases, NO + HCN, released from SNP, and $\mathrm{HCN}$ released from $\mathrm{Fe}(\mathrm{II}) \mathrm{CN}$, applied either for 1 and 3 days (Fig. 3) or continuously (Liu et al. 2011, fig. 3) stimulated germination of dormant A. retroflexus seeds. One day of treatment with the highest donor concentration was sufficient to obtain the maximal effect (Fig. 3). Prevention of the effect of SNP vapors by the commonly used NO scavenger (Table 1), cPTIO, may indicate that NO is responsible for stimulating the germination of dormant seeds of A. retroflexus. Similarly, stimulatory effect of gases released from SNP on the germination of dormant Arabidopsis seeds (Bethke et al. 2006a, b) and apple embryos (Gniazdowska et al. 2010) did not occur in the presence of cPTIO. As the stimulatory effect of $\mathrm{HCN}$ on germination of dormant seeds of $A$. retroflexus could not occur in the presence of cPTIO, the nitric oxide was probably involved in the response to cyanide. A similar relationship was noted in experiments with Arabidopsis (Bethke et al. 2006a, b) and Malus domestica (Gniazdowska et al. 2010), when HCN was used in combination with cPTIO. Staratified A. retroflexus seeds were sensitive to NO (Table 2), similarly to Arabidopsis seeds (Bethke et al. 2004). Gases released from both SNP and Fe(II)CN were also able to release dormancy in A. retroflexus seeds that were partially dormant due to dry storage; almost all seeds germinated (Fig. 4).

Experiments with stratification (Table 2) and dry storage (Fig. 1) indicated that releasing dormancy of partially dormant $A$. retroflexus seeds required a lower concentration of ethylene than $\mathrm{GA}_{3}$. Both these hormones, nitric oxide and HCN may partially substitute dry storage and stratification in partially dormant $A$. retroflexus seeds. Dry storage increased the response of A. retroflexus seeds to light, $\mathrm{GA}_{3}$ and ethylene. A transition from dormancy to the germination of A. retroflexus seeds due to dry storage or stratification might be associated with changes in biosynthesis and catabolism of gibberellins, abscisic acid and ethylene and the sensitivity to their perception. It was found that non-dormant, after-ripened, A. retroflexus seeds (Kępczyński et al. 2003b) and non-dormant, stratified, apple embryos (Kępczyński et al. 1977) produced more ethylene than the dormant ones. The after-ripening of $S$. officinale seeds induced expression genes involved in gibberellins synthesis, SoGA20ox2 and SoGA3ox2, and gibberellin breakdown, SoGA2ox6, and inhibited ethylene synthesis genes, SoACS7 and SoACO2 (Iglesias-Fernandez and Matilla 2009). In Arabidopsis seeds, the gibberellin biosynthesis gene AtGA2ox6 was down-regulated by stratification (Yamaguchi et al. 2004). It was postulated that multiple cross talk between ethylene and gibberellin was involved in after-ripening (Iglesias-Fernandez and Matilla 2009). The interaction between these regulatory factors existed at several levels. Releasing dormancy in $A$. retroflexus seeds by $\mathrm{GA}_{3}$ involved the biosynthesis of ethylene and its action (Kępczyński et al. 2003b). It was found that the expression of SoACO2 was inhibited by 
$\mathrm{GA}_{4+7}$ (Iglesias-Fernandez and Matilla 2009). Ethylene stimulated releasing Fagus sylvatica seed dormancy and inhibitor of ethylene biosynthesis increased expression of FsGA20ox1, the gibberellin synthesis gene (Calvo et al. 2004). On the other hand, $\mathrm{GA}_{3}$ enhanced ACC oxidase gene, ACC content and ethylene production. Recently, the cross talk between $\mathrm{ABA}$ with ethylene and nitric oxide has been considered for the control of seed dormancy and germination (Arc et al. 2013). The interaction between exogenous $\mathrm{ABA}$ and ethylene in the case of non-dormant A. caudatus seeds was reported; exogenous ABA could decrease the effect of ethylene on germination of nondormant A. caudatus seeds (Kępczyński et al. 2003a). Endogenous ethylene promoted the germination of ethylene response mutants of Arabidopsis by decreasing the sensitivity to endogenous ABA (Beaudoin et al. 2000). Releasing dormancy in A. retroflexus seeds by dry storage or stratification might also involve an interaction between the abscisic acid and ethylene and/or NO. NO induced releasing dormancy in apple embryos (Gniazdowska et al. 2007), increased ethylene production and decreased the sensitivity of apple embryos to exogenous ABA (Gniazdowska et al. 2007). It was also shown that NO, responsible for releasing dormancy in Arabidopsis, was required for the expression GA3ox1 and GA3ox2 (Bethke et al. 2007).

To summarize, both dry storage and stratification can remove dormancy in A. retroflexus seeds, dry storage more effectively in the light than in the darkness. $\mathrm{GA}_{3}$ and ethylene, nitric oxide and hydrogen cyanide can markedly release dormancy in the light; the light increases seed response to above plant hormones. Releasing dormancy by hydrogen cyanide requires nitric oxide. Dry storage increase the response to $\mathrm{GA}_{3}$ and ethylene. These compounds can partly substitute dry storage and stratification in partially dormant seeds. The response to $\mathrm{GA}_{3}$ and ethylene increases with the increasing temperature of dry storage.

Author contribution JK designed research, analyzed data and wrote the paper. PS conducted experiments.

Acknowledgments Authors are grateful to MSc Danuta Cembrowska-Lech for statistical analysis.

Open Access This article is distributed under the terms of the Creative Commons Attribution License which permits any use, distribution, and reproduction in any medium, provided the original author(s) and the source are credited.

\section{References}

Ali-Rachedi S, Bouinot D, Wagner MH, Bonnet M, Sotta B, Grappin P, Jullien M (2004) Changes in endogenous abscisic acid levels during dormancy release and maintenance of mature seeds: studies with the Cape Verde islands ecotype, the dormant model of A. thaliana. Planta 219:479-488

Arc E, Sechet J, Corbineau F, Rajjou L, Marion-Poll A (2013) ABA crosstalk with ethylene and nitric oxide in seed dormancy and germination. Front Plant Sci 63:1-19

Baskin JM, Baskin CC (1976) High temperature requirement fore after ripening in seeds of the winter annuals. New Phytologist 77:619-624

Baskin CC, Baskin JM (2001) Seeds ecology, biogeography, and evolution of dormancy and germination. Academic Press, San Diego

Beaudoin N, Serizet C, Gosti F, Giraudat J (2000) Interactions between abscisic acid and ethylene signaling cascades. Plant Cell 12:1103-1115

Beligni MV, Lamattina L (2000) Nitric oxide stimulates seed germination and de-etiolation, and inhibits hypocotyl elongation, three light-inducible responses in plants. Planta 210:215-221

Bethke PC, Gubler F, Jacobsen JV, Jones RL (2004) Dormancy of Arabidopsis seeds and barley grains can be broken by nitric oxide. Planta 219:847-855

Bethke PC, Libourel IGL, Jones RL (2006a) Nitric oxide reduces seed dormancy in Arabidopsis. J Exp Bot 57:517-526

Bethke PC, Libourel IGL, Reinhol V, Jones RL (2006b) Sodium nitroprusside, cyanide, nitrite, and nitrate break Arabidopsis seed dormancy in a nitric oxide-dependent manner. Planta 223:805-812

Bethke PC, Libourel IGL, Jones RL (2007) Nitric oxide in seed dormancy and germination. In: Bradford KJ, Nonogaki H (eds) Seed development, dormancy and germination, vol 27, Annual Plant Reviews. Blackwell Publishing Ltd, pp 153-175

Cadman CSC, Toorop PE, Hilhorst HWM, Finch-Savage WE (2006) Gene expression profiles of Arabidopsis cvi seeds during dormancy cycling indicate a common underlying dormancy control mechanism. Plant J 46:805-822

Calvo AP, Nicolás C, Nicolás G, Rodriguez D (2004) Evidence of a cross-talk regulation a GA 20-oxidase (FsGA20ox1) by gibberellins and ethylene during the breaking of dormancy in Fagus sylvatica seeds. Physiol Plant 120:623-630

Egley GH (1989) Some effects of nitrite-treated soil upon the sensitivity of buried redroot pigweed (A. retroflexus L.) seeds to ethylene, temperature, light and carbon dioxide. Plant Cell Environ 12:581-588

El-Maarouf-Bouteau H, Bailly C (2008) Oxidative signaling in seed germination and dormancy. Plant Signal Behav 3:175-182

Feelisch M (1998) The use of nitric oxide donors in pharmacological studies. Naunyn-Schmiedeberg's Arch Pharmacol 358:113-122

Finch-Savage WE, Leubner-Metzger G (2006) Seed dormancy and the control of germination. New Phytol 171:501-523

Gniazdowska A, Dobrzyńska U, Babańczyk T, Bogatek R (2007) Breaking the apple embryo dormancy by nitric oxide involves the stimulation of ethylene production. Planta 225:1051-1057

Gniazdowska A, Krasuska U, Czajkowska K, Bogatek R (2010) Nitric oxide, hydrogen cyanide and ethylene are required in the control of germination and undisturbed development of young apple seedlings. Plant Growth Regul 61:75-84

Gubler F, Hughes F, Waterhouse P, Jacobsen J (2008) Regulation of dormancy in barley by blue light and after-ripening: effects on abscisic acid and gibberellin metabolism. Plant Physiol 147:886-898

Hallet BP, Bewley JD (2002) Membranes and seed dormancy: beyond the anaesthetic hypothesis. Seed Sci Res 12:69-82

Hendricks SB, Taylorson RB (1974) Promotion of seed germination by nitrate, nitrite, hydroxylamine, and ammonium salts. Plant Physiol 54:304-309

Hilhorst HWM (2007) Definition and hypotheses of seed dormancy. In: Bradford KJ, Nonogaki H (eds) Seed development, dormancy 
and germination, vol 27, Annual Plant Reviews. Blackwell Publishing, Sheffield, UK, pp 50-71

Iglesias-Fernandez R, Matilla A (2009) After-ripening alters the gene expression pattern of oxidases involved in the ethylene and gibberellin pathways during early imbibition of Sisymbrium officinale L. seeds. J Exp Bot 60:1645-1661

Karssen CM, Zagórski S, Kępczyński J, Groot SPC (1989) Key role for endogenous gibberellins in the control of seed germination. Ann Bot 63:71-80

Kępczyński J, Sznigir P (2013) Response of Amaranthus retroflexus L. seeds to gibberellic acid, ethylene and abscisic acid depending on duration of stratification and burial. Plant Growth Regul $70: 15-26$

Kępczyński J, Van Staden J (2012) Interaction of karrikinolide and ethylene in controlling germination of dormant Avena fatua $\mathrm{L}$. caryopses. Plant Growth Regul 67:185-190

Kępczyński J, Rudnicki RM, Khan AA (1977) Ethylene requirement for germination of partly after-ripened apple embryo. Physiol Plant 40:292-295

Kępczyński J, Corbineau F, Côme D (1996) Responsiveness of Amaranthus retroflexus seeds to ethephon, 1-aminocyclopropane-1-carboxylic acid and gibberellic acid in relation to temperature and dormancy. Plant Growth Regul 20:259-265

Kępczyński J, Bihun M, Kępczyńska E (2003a) The release of secondary dormancy by ethylene in Amaranthus caudatus L. seeds. Seed Sci Res 13:69-74
Kępczyński J, Kępczyńska E, Bihun M (2003b) The involvement of ethylene in the release of primary dormancy in Amaranthus retroflexus seeds. Plant Growth Regul 39:57-62

Kępczyński J, Cembrowska-Lech D, Van Staden J (2013) Necessity of gibberellin for stimulatory effect of $\mathrm{KAR}_{1}$ on germination of dormant Avena fatua L. caryopses. Acta Physiol Plant 35:379-387

Liu XY, Deng ZJ, Cheng HY, He XH, Song SQ (2011) Nitrite, sodium nitroprusside, potassium ferricyanide and hydrogen peroxide release dormancy of Amaranthus retroflexus seeds in a nitric oxide-dependent manner. Plant Growth Regul 64:155-161

Schönbeck MW, Egley GH (1980) Redroot pigweed (Amaranthus retroflexus) seed germination responses to after ripening, temperature, ethylene, and some other environmental factors. Weed Sci 28:543-548

Timson I (1965) New methods of recording germination data. Nature 207:216-217

Yamaguchi Y, Ogawa M, Kuwahara A, Hanada A, Kamiya Y, Yamaguchi S (2004) Activation of gibberellin biosynthesis and response pathways by low temperature during imbibition of Arabidopsis thaliana seeds. Plant Cell 16:367-378 